\title{
Emotions in Philosophy. A Short Introduction
}

\author{
Andrzej Dąbrowski \\ University of Information Technology \\ and Management in Rzeszow, \\ Poland \\ e-mail: $\underline{\text { adabrowski@wsiz.rzeszow.pl }}$
}

\begin{abstract}
:
In recent decades, there has been a renewed attention to the emotions amongst scientists of different disciplines: psychology, psychiatry, neurobiology, cognitive science, computer science, sociology, economics, and many others. There are many research centers and scientific journals devoted to affective states already existing. However, studies of emotion have a very long history especially in philosophy (anthropology, ethics, aesthetics, epistemology, and rhetoric). Philosophers first raised many important questions about emotions and their contribution to the discovery of the nature of emotions is very important. The aim of the article is the reconstruction of the views on emotions of particular thinkers in history of philosophy.

Keywords: passions, emotions, ancient philosophy, medieval philosophy, modern philosophy.
\end{abstract}

\section{Emotions in Ancient and Medieval Philosophy}

Directly and straight the problem of emotions was dealt with by Plato [50, 51, 52, 53; see also 14, 79] and Aristotle [2, 3, 4, 5; see also 14, 54]. They studied it within their anthropological theories, especially when the soul was concerned. Plato put forward the opposition of the immortal and rational soul and irrational body. All desires and emotions he localized in the body. He saw nothing positive in greed and passion, 'because the body confuses the soul and does not allow it to acquire truth and wisdom whenever it is associated with it' [50, 66b].

Later he offered a more elaborate division. In the Republic he divided human soul into three parts: reason, spirit and appetite, and treated them as three different subjects. The former seeks for knowledge and understanding, the second for immediate sensual satisfaction, and the latter helps the two others. Though Plato put stress on the difference between the rational and non-rational parts, he did not think that spirit and appetite were irrational. What is more, according to Knuuttila, he considered emotions a detailed kind of cognitive phenomena:

Plato treats its emotional responses as cognitive. As the seat of admiration, honour, and pride, it can help the rational soul in its striving to reach knowledge and to behave in accordance with the true vision of the nature of human beings and their place in the 
universe. But in a disordered soul its passions nourish exaggerated aggression and vainglory $[43$, p. 8$]$.

Emotions were important from the point of view of many philosophical disciplines pursued by Aristotle, especially in ethics, rhetoric and poetics. The basis of those considerations was his theory of man and soul. According to him, the soul was the unity of three parts: rational, sensual and vegetative. The rational part presupposed the activity of passive and active reason, and was responsible for rational cognition; on the other hand, the sensual part presupposed senses, emotions and imagination. A basic principle of his ethics was that the man sought for the highest purposehappiness - with his whole soul. It means that emotions - as a part of it - had to be engaged in that pursuit. However, they belonged to the lower part of the soul, so they were subjected to the reason [see 3].

Aristotle claimed that emotions have a very important role in various forms of social life, attitude education, political debates, and seeking for happiness:

In his ethics and politics, Aristotle took it for granted that human beings are rational and social by nature and that a good human life involves developing human rational abilities and participating in various forms of social life (...). He thought that there is a great variety of emotions connected with social institutions and human practices, topics discussed in practical philosophy, and that it is worthwhile analyzing the cognitive content and motivating functions of emotions (...). Socially learned emotional paradigms played an important role in Aristotle's theory of moral education: its main question was how to train and instruct young people to join in the emotional patterns of culture in such a way that the habits of feelings and emotions contribute to a good life $[43$, p. 25].

Aristotle postulated that emotions were cognitive-they were based on beliefs and assessments. When a subject stood toward a situation, his emotions informed him about the meaning and value of the situation for his life. 'If someone smiles at you in a friendly way, and you feel warm to that person, it is because you evaluate the smile as a gesture of affection' [48, p. 42]. The human system of emotions was the map of our values. Additionally emotions were accompanied by pleasant or upsetting subjective experiences: 'Emotions are the things on account of which the ones altered differ with respect to their judgments, and are accompanied by pleasure and pain: such are anger, pity, fear, and all similar emotions and their contraries' [5, 1378a].

This was connected to another important property of emotions-they provoked the subject to act-they influenced our decisions and conduct. When physiological changes (often mentioned by Aristotle) were added to that characteristic you obtained a fourfold theory of emotions. It included four elements: (i) cognitive (assessing), (ii) sensational, (iii) behavioral, and (iv) physiological.

A detailed analysis of emotions can be found at Stoics [28]. The early ones preferred the cognitive approach, and maintained that emotions were assessments referring to the world, other people and oneself. However, Stoics treated them as basically inaccurate, as they were usually based on inadequate knowledge of the reality and/or erroneous opinions concerning oneself (Zeno of Citium). Some claimed a more radical thesis that actually emotions were judgments (Chrysippus) [see 27]. Whether emotions were judgments or were based on them, all Stoics believed that they were disturbances of soul and we should have eliminated them from life.

Stoics asked, how to achieve happiness in life. Their answer was simple: living in accordance with nature. Thus the ideal was to live according to the nature, and also it was the life of virtue, for the reason guaranteed the man not only to know the truth but also to know the good. The worst obstacles in rational life included desires and passions, for they governed people and also deceived them. According to Zeno, the passion is an unreasoning movement of the soul that is contrary to the nature. He maintained that there were four basic kinds of passion: sorrow, fear, 
desire, and delight [see 24, VII, 111]. Many various emotions belonged to those four kinds. Nevertheless stoic apatheia did not mean entire lack of feelings. That was because, save violent and strong emotions, there were also good emotions (eupatheiai), and they were not against the reason. Joy, reasonable desire, sympathy or love are suitable there. Stoics were very much interested in them. ${ }^{1}$

In Middle Ages, Christian thinkers were influenced by their religious doctrine, but on the other hand, they referred to previous theories of emotions, especially to Plato, Aristotle, and Stoics. When Saint Augustine held that there was a specific level of emotions in the soul, he alluded Plato. In his opinion the soul felt emotions through the body. That resulted with the thesis that beings having no body - as God or angels-did not experience emotions. On the other hand, Augustine made many valuable remarks. For instance, as one of the first he put forward the problem of emotional memory. He discusses memories of emotions: 'The same memory contains also the affections of my mind, not in the same manner that my mind itself contains them, when it feels them; but far otherwise, according to a power of its own' [7, 10.14.21]. An interesting answer to that question has been given only by modern cognitive psychology; a particular emotional memory subsystem in the brain has been indicated.

The Augustine's theory was referred to by Thomas Aquinas. He distinguished the cognitive and the passion sphere (underlining their close relationship). He divided the latter into volitional and sensual ones. Emotions belonged to the sensual passion sphere. The cognitive meant directing to an object, and the passion relied on active movement. An emotion was a kind of desire or movement. Movements were caused by sensual data. An emotion was an act of receiving the content from senses (external or internal) connected with becoming aware that it was pleasant or upsetting, useful or harmful. For emotions were to a degree in the body, Thomas took into account the aspect of physiological changes. As Peter King notices:

Aquinas's theory of the emotions (passions animae) is cognitivist, somatic, and taxonomical: cognitivist because he holds that cognition is essential to emotion; somatic because he holds that their physiological manifestations are partially constitutive of emotions; taxonomical because he holds that emotions fall into distinct natural kinds which are hierarchically ordered [41, p. 209].

Medieval analyses of emotions were often a part of consideration concerning internal experience and formation based on Christian spirituality. Many important questions were raised in connection with mental faculties (especially the will) and logical competence. An impulse was given by earlymedieval Latin translations of philosophical and medical works. Besides Augustine and Thomas, emotions were dealt with by Avicenna, Albertus Magnus, Duns Scotus, William of Ockham [43, pp. 177-286].

\section{Emotions in Early Modern Philosophy}

In the modern era, emotions were pondered on mainly in the junction area of epistemology and metaphysics (analysis of the human mind) and also of ethics and axiology (the problem of having any contact with the sphere of values). In that manner emotions were considered by Descartes, Pascal, Hobbes, Spinoza, Shaftesbury, Hutcheson, Hume, Kant and many others [see 1; 21]. Below I will refer only to a few of them.

Both Descartes and Spinoza were rationalists but their ontological positions and views about emotions were different. The former maintained that emotions are bodily appearances, though they are closely connected to the soul. The latter held that they are purely cognitive phenomena, i.e. thoughts. On the other hand, studying in detail their theories does not seem to be so far one from another. Descartes defined emotions-passions ambiguously as perceptions, impressions or affections caused, maintained and amplified by some movement of animal spirits (Latin spiritus animales, French esprits animaux) that had place in the brain, and they were able to wander 
throughout whole the body by nerves. Here is the relevant passage: 'the perceptions, sensations, or commotions of the soul which we relate particularly to the soul and are caused, maintained, and strengthened by some movement of the spirits' [22, art. 27].

Since Descartes stressed the bodily aspect of emotions, one can say that his theory anticipated modern neurophysiological theories. On the other hand, since this definition relied on the view that passion was perception (so it was a mental state), the theory should be treated as a variant of the cognitive approach. From the point of view of Descartes' ontological dualism of substance, there is no doubt that passions and any feelings belonged to the mental substance. Some readers maintain that the identity of a passion was fixed by its sources, and, firstly, they appeared in the body, especially in the brain [see 55]. Finally it is probable that emotions went on in the borderland between the body and the mind: 'Descartes has attempted to create a hybrid psychology, giving space both to immaterial and to material aspects of the 'mechanism' of cognition and emotion' [36, p. 68].

Additionally it is worth to mentioning the functional aspect of Descartes' theory. The aim of passions was to prevail on the soul that it needed what they made the body ready for: to run away in fear, to fight in courage. According to Descartes simple and basic passions were only six: wonder, love, hatred, desire, joy, and sadness. Any good and evil in our live depended on them, mostly.

Spinoza held that our cognitive states and emotions belonged to the same kind of mental states (that is why he is often found a continuator of stoic tradition). What is important, he formed his philosophical approach in opposition to Descartes. He regarded him and criticized in the same time; he claimed that Descartes' theories were full of inexactnesses and errors. In his opinion they had little to contribute to science about affections:

I know, of course, that the famous Descartes, although he too believed that the mind has absolute power over its own actions, nevertheless sought to explain human affects through their first causes, while also showing how a mind can have absolute dominion over its affects. But in my opinion, he showed nothing but the cleverness of his intellect, as I shall show in the proper place [66, Preface to Part III].

First of all, Spinoza did not accept Descartes' idea of the body and soul dualism. In his opinion there was only one living nature (substance, God), and it was full of movements, and the body and the soul were its integral parts. The mind came out of the substance equally as the body did. What happened to the mind, happened to the body, and what happened to the body, happened to the mind. ${ }^{2}$ According to Damasio, Spinoza '...suggested that the body shapes the mind's contents more so than the mind shapes the body's, although mind processes are mirrored in body processes to a considerable extent' $[17$, p. 217]. Nevertheless, shortly after he notices that 'On the other hand, the ideas in the mind can double up on each other, something that bodies cannot do' $[17,217]$.

As an affect Spinoza meant a movement of the body:

D3: By 'affect' I understand states of a body by which its power of acting is increased or lessened, helped or hindered, and also the ideas of these states. Thus, if we can be the adequate cause of any of these states, the affect in question is what I call an 'action'; otherwise it is a 'passion' [66, III, 3].

According to Spinoza, affections were passive or active, and only the latter ones express our true nature, increase the experience of consciousness, control and activity. Passive affections had the power over the subject, and he had no control over them. Active ones stimulated the subject to act. Further, affects were able to appear gradually or suddenly. They might have been strong or weak (so they were gradable). Active ones were able to inspire broadly various activities: 'Different men can be affected differently by one object; and one man can be affected differently at different times by one object' [66, III, P51, p. 70]. In the realm of affections, there were no simple and easy mechanisms to predict effects or reactions. 
Spinoza enumerated a long list of definitions of varies emotions. Most of them he added a comment. Here are the first ten ones:

1. Desire is a man's essence, insofar as it is conceived to be determined, from any given state of it, to do something.

2. Pleasure is a man's passing from a lesser perfection to a greater.

3. Unpleasure is a man's passing from a greater perfection to a lesser.

4. Wonder is an imagining of a thing in which the mind remains fixed because this particular imagining has no connection with any others.

5. Disdain is an imagining of a thing that makes so little impact on the mind that its presence moves the mind to imagining what is not in it more than what is.

6. Love is a pleasure accompanied by the idea of an external cause.

7. Hate is unpleasure accompanied by the idea of an external cause. Explanation: The things to be noted here can easily be seen from what I have just said in explaining 'love'.

8. Inclination is pleasure accompanied by the idea of a thing that is the accidental cause of the pleasure.

9. Aversion is unpleasure accompanied by the idea of something that is the accidental cause of the unpleasure.

10. Devotion is a love of someone whom we wonder at [66, III, p. 76-78].

I have already mentioned the strong similarity of Spinoza's and Stoic thought. Both believed that men were a part of nature and that we were governed by the system of the world as all the other units. Stoics maintained that our nature was a part of the nature of the universe, whereas Spinoza claimed that it was not possible that man was not a part of nature. Free will, in the meaning of choice between two available options, was determined by causal chains. Stoics believed that the free will of a man was limited, and first of all it relied on knowing the reality. Freedom meant also to cast out emotions, appetites, and desires. Decidedly emotions did not give freedom or happiness to a man. According to Spinoza, the will was not a free but necessary cause. Human activity was directed also by emotions but Spinoza (contrary to Stoics) did not see anything wrong in it. The challenge for a man was to know and accept the nature of things, his own emotionality included. To liberate meant to understand the source and nature of emotions and accept them.

What Kant did for theoretical and practical philosophy was groundbreaking, but not so much in the area of emotions. They were quite far from his main interest. He did not develop any coherent theory of them. Instead he echoed numerous negative views concerning emotions, that is, that they were impetuous, obsessive, antisocial, selfish, and even evil. On the other hand, he made many important and positive remarks about emotions, and the conclusion was that you should not have them ignored, especially in moral life (these remarks are limited to the 'critical' period; are not concern to later works, e.g. Anthropology from a Pragmatic Point of View).

It is known that Kant's ethics was rationalistic, formalistic, and universalistic. The former feature-I will talk about the rationalism only here-relied on that any moral action had to be based on reason and duty. That was a view different from for example emotivism (that ascribed the basic role to emotions). When studied in detail it occurs that Kant did not ignore emotions and feelings, but reversely, he thought that a man should have been open and sensitive to the affective sphere (Gefühl, Affekt, and Rührung). You can find the affirmation of that sphere in later Kant's works, especially in his Critique of Judgement. Generally according to Kant emotions and feelings helped us to recognize our moral duties toward oneself and especially toward others. 'Without a sensitivity to moral feeling, we are likely to ignore the moral dimension of our lives entirely' [74, p. 9].

Shaftesbury was interested-as many other English philosophers of the 18th century-in the essence of the moral experience. In his opinion the source and the basis of morals lay in human nature, and that was composed of psychic powers mainly. Among them, Shaftesbury distinguished the moral sense - the feeling of righteousness - as a discrete psychic ability. The sense allowed to differ good from evil, and feelings were important in that. He claimed that there were three kinds of 
feelings. First, there were natural feelings leading to do other people good, sympathy belonged to them. The second were natural egoistic feelings, and the third-unnatural ones, as for example pleasure of unhappiness (i.e. malice, jealousy). The harmony between feelings of the first and the second kind was the virtue, and bad was to indulge in feelings of the third kind. Egoistic feelings were not the source of evil themselves. The bad was to disturb the harmony. Shaftesbury's moral sense was mainly of emotional character; however, it was connected with reason too. In that idea Shaftesbury combined in a detailed way the intellectual intuition and the moral experience. He influenced Francis Hutcheson, and by that way David Hume and Adam Smith. Shortly about Hume is then.

Hume's studies over emotions (more strictly 'passions') were a part of his investigations concerning human nature. He strived to explain the raise and development of feelings by a few simple principles, the principle of association included. Additionally he used a few categories, as cause, object, and first-person subject (ego). Unlike Descartes he treated feelings as mental par excellence; started his considerations with a few divisions.

According to Hume, all perceptions were divided into impressions and ideas. Further, impressions were divided into sensual and reflexive. The former arose in mind without any previous perceptions, by things acting upon external organs. Reflexive impressions came out of the former ones or of our ideas. Generally pleasures and annoyances of the body, desires, passions, feelings and emotions belonged to them (at Hume's the term 'emotion' meant a movement and referred to everything that caused a change). Reflexive impressions were divided into two kinds: gentle and violent. The first kind includes the feeling of beauty and ugliness in actions, external objects, and art; the second includes love, hate, sadness, joy, pride, and humility. He underlined that division was far from precision.

Besides, Hume divided feelings into direct and indirect. The former resulted from experiences of pleasure or pain. Such emotions like hunger, thirst, desire, and also disgust, sadness, hope, fear, and despair belonged here. The latter were more compound and arose upon connections between impressions and ideas, and strictly upon the double relation between them. Indirect feelings were: pride, humility, ambition, vanity, love, hate, jealousy, mercy, malice, nobility, and other connected to those.

There is a well-known (and difficult to interpret) Hume's saying: 'Reason is, and ought only to be the slave of the passions, and can never pretend to any other office than to serve and obey them' $(38$, p. 415). That view puts Hume in opposition to strong rationalism (in theory of action) claiming that the reason directs the activity, even if sometimes it has to collaborate with the will, and it is the reason who establishes goals and schedules means to obtain them, permanently monitors the activity and assesses the results. Instead, according to Hume, the superior and directorial function in activity was assigned not to reason but to emotions and desires, since the reason was-as Hume comprehended that-passive and powerless toward the activity sphere. His concept of reason was very narrow. As reason he meant the tool that enabled correct reasoning, and the power to tell truth from false. Partly_as I think-it explains why Hume thought the reason was a slave.

\section{Emotions in Modern Philosophy}

The variety of problems that philosophers deal with is widely vast. The basic questions are: what are emotions? Do they comprise a natural kind? What are the differences between them and impressions, sensations, affections, feelings, moods etc.? Are there any specific moral and/or aesthetic emotions? What is the role that the body, the brain, the mind, the external environment, the society and the culture play in emotional formation? What is the influence of emotions upon cognitive processes (attention, perception, memory, imagination, thinking)? What is their relation to consciousness (and to unconscious processes and states)? Are they intentional? Are they represented in the mind and in what way? Are they rational? (And if so, in what meaning?) What is the essence of their motivational function (emotions and activity)? What emotions are for-what 
are their functions? What is their role in morality? What is their role in creating and receiving a piece of art?

Instead of presenting problems connected with emotions, even a very brief one, next I offer a short characteristic of three kinds of a theory and research concerning emotions: phenomenological, cognitive, and physiological.

Phenomenology. The development of phenomenology was strongly influenced by Franz Brentano. His studies were focused on psychic and moral life of a man. He distinguished three basic kinds of psychic phenomena: presentations, judgments, and emotions. In his opinion, all they were intentional, that is, directed to an object. Their character was mental, intentional, and also cognitive-moral knowledge stemmed from the emotional sphere of man (later the idea was taken up also by Max Scheler). One of Brentano's pupils, Edmund Husserl also analyzed emotional phenomena, though they were not the main his focus. M. Scheler, E. Stein, M. Heidegger and J. P. Sartre concentrated on emotions more than others [see 35].

According to Scheler, people were not rational but rather emotional beings. Emotions accompanied a man from his birth to his death and appeared in every layer of his existence, first of all in his axiological and moral life. He believed that ethics should have been based on the internal experience of reality, and that was not only objects but values too. It was not possible to reduce values to anything more basic, e.g. something material. Emotions helped to know values-we grasped them directly in emotional experiences. In sensations their specific content and worthiness was revealed. Moreover, Scheler was interested in stratification of emotional experiences. He distinguished sensual, vital, psychic, and spiritual emotional states. The most important was his distinction between emotional states (Gefühlzustand) and feeling something (Fühlen von Etwas): (1) feeling one's own body, (2) feeling one's own experiences, mental states, (3) feeling values. Besides he differentiated two kinds of intentional acts: (1) acts of prioritizing or shutting out values and (2) acts of love or hate. The latter were fundamental axiological experiences [see 61, pp. 32$344]$.

In her thesis On the Problem of Empathy, Stein focused on the titular problem of feeling-in (Einfuhlüng) and emotions. The latter were the result of mutual interaction between two basic elements: somatic and psychic. In reference to the body Stein observed that it was constitutive in two ways: as the experiencing living body (Leib) and as an externally perceived physical body (Körper). A body was my own body if I received it through impressions (of warm, pain, light etc.). In a living body, there were plenty of impressional areas. Those impressions delivered information about the world that surrounded us. They comprised the foundation for a kind of feelings (anxiety, joy, sadness). According to Stein there were also feelings-psychic feeling-that were not connected to the body, but came from somewhere in the depth of the subjective ego. The most important in that approach was that some energy was inscribed in emotions and it caused an expression or an action. A feeling, according to its pure nature, is not closed in itself: but it is as if full of energy that has to be discharged. That discharge may go on in different ways 'Feeling in its pure essence is not something complete in itself. As it were, it is loaded with an energy which must be unloaded' [68, p. 51].

Sartre's concept of emotion was a part of his philosophy of consciousness. According to him, consciousness was experienced in the body (it was characterized by corporality-it existed only, if it was embodied), and in time (it was characterized by temporality-it existed only, if it went on in time). The emotional consciousness was the pre-reflective consciousness of the world. That was one of the ways to experience the world, and more, it was 'transformation of the world' [60].

Heidegger studied emotions and moods within his ontology. He distinguished beings (things) of the world from human existence. The latter stood toward them and toward the mysterious Sein. Human being was experiencing and opened to the world. Moods (care, fear) connected a man with the being encountered in the world and determined its ways of existence [see 35]. 
Typical feature of phenomenological (and similar) analyses was to refer the idea of pretheoretical experience.

The cognitive perspective. Cognitive theories, proposed by E. Bedford, J. Marks, W. Lyons, M. Nussbaum, R. Solomon and many others, explain emotions by thoughts, beliefs or judgments. There have been plenty of philosophical arguments presented to defend that approach. Some researchers claim that the simple argument is that we use rational-cognitive vocabulary in emotion assessment: 'rational', 'justified', 'legitimate', 'sensible', 'adequate' etc. Supporters of cognitive theories assume-though it is not always fully intended-that emotions require concepts and beliefs, and also more or less clearly the somatic and the cognitive spheres are distinguished. The latter is located somewhere above changes in the body. Those changes are not relevant to emotion arising. Proponents of various cognitive theories underline such properties of emotions as: intentionality, cognitive character, conceptualization, dependence on thoughts, beliefs or judgments, ability to event assessment.

A variant of cognitive approach is the theory by W. Lyons [see 44]. The author of Emotion presented it in the context of criticizing classic theories: affectional, behavioral, psychoanalytical, and different cognitive ones. In his opinion, all positions that omitted the cognitive component were false, for emotions to a degree were based on beliefs and knowledge. However, you could not have them reduced to the cognitive element-such answers were wrong. Exploiting some results by E. Bedford, A. Kenny and L. Wittgenstein, Lyons offered his own causal-evaluative concept of emotions. He strived to reconcile physiological approach with a cognitive theory where evaluation had an important role. He maintained that emotions arose when physiological changes were caused by evaluative activity. The evaluation was not an objective cold assessment but a subjective one. He took into account the affectional and behavioral aspects, too.

The next (strong) variant of cognitive theory is-favored by analytic philosophypropositional approach (actually it was at Stoics already). The idea to treat mental phenomena as propositional attitudes came out of formal language analyses offered by B. Russell. Propositional attitudes are internal intentional states of a subject-simple thoughts as beliefs, desires, feelings, expressed in language by the subject: ' $P$ claims that $x$,' ' $P$ fears that $y$,' ' $P$ loves $z$ ' etc. In every such a sentence you can distinguish a verb, connective 'that,' and a sentence having the content $x$. When they apply that approach to emotions they assume that emotional attitudes are intentionally directed to an object. And also it is assumed that the subject possesses a language and some cognitive-conceptual structures. If ' $S$ fears that a dog bites him' then it is necessary that $S$ possesses the concept of a dog as a living being with teeth, and that in some situations that animal may attack a man. If ' $P$ loves $Z$ ' then $P$ has to be convinced that $Z$ is beautiful, sensitive and intelligent or that she has some other features that attract him. In that theory emotions are treated as an element of rational thinking (cognition), and basic compounds of that are concepts and beliefs. ${ }^{3}$

The physiological-somatic perspective. Commonsense forces us to assume that when one perceives some objects or situations then it stimulates his emotional states and that those states evoke changes in the body. Contrary to this, James' physiological theory claimed that somatic changes were the immediate result of the fact causing the stimulus and that an emotion was when one felt those changes when they appeared [see 39].

Contemporarily, Jesse Prinz declaims against cognitive theories and stands for the physiological-somatic approach [see 55]. From his point of view, emotions are closely connected to changes in the body - they are automatic embodied assessments, and they carry out the evaluation upon the delivered information: 'Emotions are gut reactions; they use our bodies to tell us how we are faring in the world' [55, p. 69]. An important element of his theory is a kind of perceptionperceiving somatic changes. Emotions are perceptions and representations-they represent core relational themes. Let me give some more details about his theory.

The word 'embodied' signalizes a close correlation with the body, and even more-the genesis of emotions. According to Prinz, bodily changes evoke emotional states. Emotions are perceptions of stimulated states of the body (somatic changes) that are expressed in assessments. To assess $X$ means to grasp $X$ as a form of representation. Therefore, if emotions are evaluations, they 
have to be representations. However, they do not represent usual objects or events. Next to common and particular objects, Prinz assumes formal ones, and they are what is represented. A formal object is a property by which an object or an event triggers emotions. For example, the death of a child may be the cause of one's sadness. That death is a particular object (an objective fact), and in the same time, for it is the reason of one's sadness, that is a formal object of the sadness. It means that a state of mind (sadness after a child's death) has two kinds of object: (1) a particular object (a child's death) and (2) a formal one (loss of a child). The sadness represents the loss-elimination of something precious. Emotions represent relative properties. Prinz calls them core relational themes. The core relational themes of sadness are the loss, fear (or fright) is about danger. He took that expression from Lazarus, though he did not agree with him that core relational themes corresponded with assessments in the head. They were something external, and they did not comprise an internal structure of emotions or any mental states [see 55, p. 65].

In the conclusion of the third chapter, Prinz wrote: To qualify as an appraisal, a state must represent an organism-environment relation that bears on well-being. On the view I have been defending, emotions qualify as appraisals in this strict sense. They represent core relational themes.

I have also argued that emotions monitor our bodily states. Emotions represent changes in organism-environment relations by tracking changes in the body. They appraise by registering patterned physiological responses. This, I said, marks a major reconciliation. The tradition that associates emotions with appraisals is generally presumed to be at odds with the tradition that identifies emotions with changes in physiology. I am suggesting that this division is spurious. Emotions are states that appraise by registering bodily changes. I call this the embodied appraisal theory. Loosely speaking, palpitations serve as evaluations. Theodore Roethke said: 'We think by feeling.' Or one might say, heading the lessons of chapter 2, we feel instead of thinking. Feelings can obviate the need for cognition, because feelings carry information. The discrete motions of our bodies convey how we are faring in the world [55, pp. 77-78].

Today philosophers that systematically study the nature of emotions are A. Ben-Ze'ev, M. Brady, J. Deigh, C. DeLancey, J. Deonna, R. de Sousa,P. Greenspan, P. Goldie, R. Gordon, P. Griffiths, B. Helm, W. Lyons, K. Mulligan, M. Nussbaum, K. Oatley, J. Prinz, Roberts, A. Rorty, M. Salmela, M. Stocker, Ch. Tappolet, F. Teroni, R. Wollheim.

Many of them offer more or less sophisticated theories. One of the most elaborate is the Roberts' one. In his approach, emotions are kind of synthetic constructions, and he calls them 'construals.' It is not easy to explain what they are. Mostly by their immediateness they are similar to sensual perceptions-kind of impressions. However, they are not impressions purely sensual, as an impression caused by light falling at retina, for they possess intellectual-conceptual aspect, too. In his characteristic, Roberts enumerates many properties of construals. Here are some of them:

1. Construals have an immediacy reminiscent of sense perception. They are impressions, ways things appear to the subject; they are experiences and not just judgments or thoughts or beliefs $[\ldots]$.

2. Though they are impressions, they are not, or not merely, sense impressions, that is, impressions of the sort produced by light hitting the retina, air vibrations exciting the ear drum, and so on.

3. They involve an "in terms of" relationship: one thing is perceived in terms of something else. Construals are "constructive," "synthetic," and "organic," bringing together a variety of elements in some kind of integration.

4. They are "subjective," that is, highly dependent on special qualifications of the subject; but some of them can be true or false.

5. They admit of a focus on one or two of the elements, with the rest of the construct in the "background," and the focus can be quite shifty, producing kaleidoscopic variations on a construal.

6. Opposed construals of something tend to exclude each other, but for an adept it is sometimes possible to engage two opposite construals at the same time. 
7. They need not be states of consciousness.

8. They often, but not always, have an "emotional" character, and the difference between the two kinds of cases is made by the presence of concerns, personal interests, and attachments of the subject for (to) something in the construed situation.

9. They come in degrees of depth of impression or impact of strikingness.

10. They come in varieties of interplay of mental event types.

11. They are sometimes subject to voluntary control, and they sometimes are not.

12. The language of construal or seeing-as is not native to the experience except in special cases where the experience is taken to be optional or not to bear on truth, or the speaker is denying, doubting, or analyzing the experience [56, pp. 75-76].

This overview-it has to be cursory-reveals that philosophical research concerning emotions has been conducted in various contexts and included many questions of different kinds. More details you can find in literature of the subject [contemporarily quite wide already, e.g. 21; 30; 58]. Some problems have been solved, some-eliminated as pseudoproblems, and some wait to be sorted out. Those philosophical analyses are not pointless. They are important not only for the development of philosophy itself - theoretical (as epistemology, philosophy of mind, philosophy of language, philosophy of science), and practical one (as ethics, axiology, social and political philosophy)—but also for other disciplines of science. Finally they are also important from practical point of viewthey influence economic, social and political life, and also culture and civilization.

\section{References}

1. Abramson, K. A Sentimentalist's Defense of Contempt, Shame, and Disdain. In. P. Goldie (ed.). The Oxford Handbook of Philosophy of Emotion. Oxford University Press: Oxford, 2010, pp. 189213.

2. Aristotle. De Interpretatione. In. J. Barnes (ed.). Complete Works of Aristotle. Vol. 1: The Revised Oxford Translation by Aristotle. Princeton University Press: Princeton, 1984, pp. 36-61.

3. Aristotle. On the Soul. In. J. Barnes (ed.). op. cit., 1984, pp. 872-943.

4. Aristotle. Nicomachean Ethics. Complete Works of Aristotle. Vol. 2: The Revised Oxford Translation by Aristotle. Princeton University Press: Princeton, 1984, pp. 669-836.

5. Aristotle. Rhetoric. In. J. Barnes (ed.). op. cit., 1984, pp. 1228-1378.

6. Arnold, M. Emotion and Personality. Columbia University Press: New York, 1960.

7. Augustine. Confessions. Transl. by H. Chadwick. Oxford University Press: Oxford, 1991.

8. Augustine. The Trinity. Transl. by S. McKenna. Catholic University of America Press: Washington, 1963.

9. Audi, R. The Cambridge Dictionary of Philosophy. Cambridge University Press: Cambridge, 1995.

10. Bedford, E. Emotions. Proceedings of the Aristotelian Society, 57, 1957, pp. 281-304.

11. Ben-Ze'ev, A. The Subtlety of Emotions. MIT Press: Cambridge MA, 2000.

12. Blackburn, S. Ruling Passions. Oxford University Press: Oxford, New York, 1998.

13. Brady, M. Emotional Insight: The Epistemic Role of Emotional Experience. Oxford University Press: Oxford, 2013.

14. Boudouris, K., Adam, M. (eds.). Greek philosophy and the issues of our age. Vol. 1. Ionia Publications: Athens, 2009.

15. Campe, R., Weber, J. Rethinking Emotion: Interiority and Exteriority in Premodern, Modern and Contemporary Thought. De Gruyter GmbH: Berlin/Boston, 2014.

16. Darwin, Ch. The Expression of the Emotions in Man and Animals. Harper Collins: London, 1998 [1896].

17. Damasio, A. Looking for Spinoza: Joy, Sorrow, and the Feeling Brain. Harvest Books: Washington, 2003. 
18. Davies, B., Stump, E. (eds.). The Oxford Handbook to Aquinas. Oxford University Press: Oxford, 2012.

19. Deigh, J. Emotion, Values, and the Law. Oxford University Press: New York, 2008.

20. DeLancey, C. Passionate Engines: What Emotions Reveal About Mind and Artificial Intelligence. Oxford University Press: Oxford, 2001.

21. Deonna, J. A., Teroni, F. The Emotions: A Philosophical Introduction. Routledge: London, 2012.

22. Descartes, R. The Passions of the Soul. In. The Philosophical Writings of Descartes. Vol. 1. Transl. by J. Cottingham, R. Stoothoff, and D. Murdoch. Cambridge University Press: Cambridge, 1984 [1649], pp. 325-404.

23. De Sousa, R. The Rationality of Emotion. MIT Press: Cambridge MA, 1987.

24. Diogenes Laertius. Lives of the Eminent Philosophers (two vol. ed.). Loeb Classical Library: 1925.

25. Ebbersmeyer, S. (ed.). Emotional Minds: The Passions and the Limits of Pure Inquiry in Early Modern Philosophy. De Gruyter: Berlin, 2012.

26. Elster, J. Alchemies of the Mind: Rationality and the Emotions. Cambridge University Press: Cambridge, 1999.

27. Galen, P. de Lacy (ed.). De placitisHippocratis et Platonis, Corpus MedicorumGraecorum. Akademie-Verlag: Berlin, 1978-1984.

28. Gill, C. Stoicism and Epicureanism. In. P. Goldie (ed.). The Oxford Handbook of Philosophy of Emotion. Oxford University Press: Oxford, 2010, pp. 143-165.

29. Goldie, P. The Emotions: A Philosophical Exploration. Oxford University Press: Oxford, 2000.

30. Goldie, P. (ed.). The Oxford Handbook of Philosophy of Emotion. Oxford University Press: Oxford, 2010.

31. Gordon, R. The Structure of Emotions. Cambridge University Press: Cambridge, 1987.

32. Greenspan, P. Emotions and Reasons: an Inquiry into Emotional Justification. Routledge: Chapman and Hall: New York, 1988.

33. Greenspan, P. Practical Guilt: Moral Dilemmas, Emotions and Social Norms. Oxford University Press: New York, 1995.

34. Griffiths, P. What Emotions Really Are: The Problem of Psychological Categories. University of Chicago Press: Chicago, 1997.

35. Hatzimoysis, A. Emotions in Heidegger and Sartre. In. P. Goldie (ed.). The Oxford Handbook of Philosophy of Emotion. Oxford University Press: Oxford, 2010, pp. 215-235.

36. Harré, R. Cognitive Science. A Philosophical Introduction. Sage: London, 2002.

37. Helm, B. Emotional Reason: Deliberation, Motivation and the Nature of Value. Cambridge University Press: Cambridge, 2001.

38. Hume, D. Treatise on Human Nature. Oxford University Press: Oxford, 2000 [1739].

39. James, W. What is an Emotion? Mind, 9, 1884, pp. 188-205.

40. Kenny, A. Action, Emotion and Will. Routledge and Kegan Paul, Humanities Press: London, New York, 1963.

41. King, P. Emotions. In. B. Davies, E. Stump (eds.). The Oxford Handbook to Aquinas. Oxford University Press: Oxford, 2012, pp. 209-226.

42. King, P. Emotions in Medieval Thought. In. P. Goldie (ed.). The Oxford Handbook of Philosophy of Emotion. Oxford University Press: Oxford, 2010, pp. 167-187.

43. Knuuttila, S. Emotions in Ancient and Medieval Philosophy. Oxford University Press: Oxford, 2004.

44. Lyons, W. Emotion. Cambridge University Press: Cambridge, 1980.

45. Marks, J. A. Theory of Emotion. Philosophical Studies, 1982, 42, pp. 227-242.

46. Mulligan, K. From Appropriate Emotions to Values. Monist, 81 (1), 1998, pp. 161-88.

47. Nussbaum, M. Upheavals of Thought: The Intelligence of Emotions. Cambridge University Press: Cambridge, 2001.

48. Oatley, K. Emotions: A Brief History. Blackwell: Malden, 2002. 
49. Oatley, K., Jenkins, J. M. Understanding Emotions. Blackwell: Oxford, 1996.

50. Plato. Phaedo. In. J. M. Cooper (ed., with introduction and notes), D. S. Hutchinson (associate editor). Complete works. Hackett Publishing Co.: Indianapolis, Cambridge, 1997, pp. 49-100.

51. Plato. Philebus. In. J. M. Cooper (ed., with introduction and notes). op. cit., 1997, pp. 398-456.

52. Plato, Phaedrus. In. J. M. Cooper (ed., with introduction and notes). op. cit., 1997, pp. 506-556.

53. Plato, Republic. In. J. M. Cooper (ed., with introduction and notes). op. cit., 1997, pp. 971-1223.

54. Price, A. W. Emotions in Plato and Aristotle. In. P. Goldie (ed.). The Oxford Handbook of Philosophy of Emotion. Oxford University Press: Oxford, 2010, pp. 121-142.

55. Prinz, J. Gut Reactions: a Perceptual Theory of Emotion. Oxford University Press: Oxford, 2004.

56. Roberts, R. C. Emotions: An Essay in Aid of Moral Psychology. Cambridge University Press: New York, 2003.

57. Robinson, J. Deeper than Reason: Emotion and its Role in Literature, Music, and Art. Oxford University Press: Oxford, 2005.

58. Rorty, A. (ed.). Explaining Emotions. University of California Press: Los Angeles, 1980.

59. Salmela, M. Shared Emotions. Philosophical Explorations, 15 (1), 2012, pp. 33-46.

60. Sartre, J.-P. The Emotions: Outline of a Theory. Philosophical Library: New York, 1948.

61. Scheler, M. Formalism in Ethics and Non-formal Ethics of Values: A New Attempt Toward the Foundation of an Ethical Personalism. Transl. by M. S. Frings, R. L. Funk. Northwestern University Press, 1973.

62. Solomon, R. Emotions and Choice. In. A. Rorty (ed.). Explaining Emotions. University of California Press: Los Angeles, 1980, pp. 251-81.

63. Solomon, R. The Passions: The Myth and Nature of Human Emotions. Doubleday: New York, 1984.

64. Solomon, R. C. (ed.).Thinking About Feeling: Contemporary Philosophers on Emotions. Oxford University Press: Oxford, New York, 2004.

65. Spinoza, B. Ethics. In. The Collected Writings of Spinoza. Vol. 1. Transl. by E. Curley. Princeton University Press: Princeton, 1985.

66. Spinoza, B. Ethics Demonstrated in Geometrical Order. Transl. and updated by J. Bennett. 2004. Available at: http://www.earlymoderntexts.com/assets/pdfs/spinoza1665part3.pdf.Retrieved 01.08.2016.

67. Stocker, M., Hegeman, E. Valuing Emotions. Cambridge University Press: Cambridge, 1992.

68. Stein, E. On the Problem of Empathy: The Collected Works of Edith Stein (3rd Volume). Transl. by W. Stein. ICS Publications: Washington, 1989.

69. Tappolet, Ch. Emotions and the Inelligibility of Akratic Action. In. S. Stroud, Ch. Tappolet (eds.). Weakness of Will and Practical Irrationality, 2003,pp. 97-120.

70. Tappolet, Ch. Emotion, Motivation, and Action: the Case of Fear. In. P. Goldie (ed.). The Oxford Handbook of Philosophy of Emotion. Oxford University Press: Oxford, 2010, pp. 325-345.

71. Thagard, P. Coherence in Thought and Action. MIT Press: Cambridge MA, 2005.

72. Thagard, P. Hot Thought: Mechanisms and Applications of Emotional Cognition. MIT Press: Cambridge MA, 2006.

73. Thomas Aquinas. Summa theologiae. P. Caramello (ed.). Marietti: Turin, 1948-1950.

74. Williamson, D. Kant's Theory of Emotion: Emotional Universalism. Palgrave Macmillan Press: New York, 2015

75. Wilson, J. R. S. Emotion and Object. Cambridge University Press: Cambridge, 1972.

76. Wittgenstein, L. Philosophical Investigations. Transl. by G. E. M. Anscombe. Macmillan: New York, 1953.

77. Wollheim, R. On the Emotions. Yale University Press: New Haven, 1999.

78. Zaborowski, R. Feeling-Thought Linkage and its Forms in the Ancient and Modern Times. In.

K. Boudouris, M. Adam (eds.). Greek philosophy and the issues of our age. Vol. 1, Ionia Publications: Athens, 2009, pp. 230-240.

79. Zaborowski, R. Some Remarks on Plato on Emotions. Mirabilia, 15 (2), 2012, pp. 141-170. 
80. Zaborowski, R. Plato and Max Scheler on the Affective World. Organon, 47, 2015, pp. 65-81.

\section{Notes}

1. Sensations (and the accompanying physiological changes), that were connected with emotions, were treated as movements preceding emotions. The concept was used in later stoic theory of first movements (primus motus) or pre-emotions (propatheia, Latin antepassio or propassio).

2. Of course as usual there are many various interpretations of the relation between body and mind and vice versa in that theory.

3. P. Griffiths criticized the propositional attitude theory: 'In this book, I reject propositional attitude theories in two ways. First, I reject them on a substantive level. I show in chapter 2 that all major variants of the program face substantial objections and that the research program as a whole has a range of standing problems on which it has made little progress. Second, and more important, I reject them methodologically. The adherents of propositional attitude theories have relied almost entirely on conceptual analysis to derive their account of emotion. I suggest that these epistemological foundations will no longer bear the weight' [30, p. 2]. 